DOI: 10.17707/AgricultForest.63.1.04

\title{
Vida CHALAVI, Sodabeh ZAREH \\ GENETIC ENGINEERING OF ROSE SCENTED GERANIUM WITH BACTERIAL GENES FOR PHYTOREMEDISTION OF POLYCHLORINATED BIPHENYLD
}

Polychlorinated biphenyls (PCBs) are major water and soil contaminants worldwide. These harmful compounds to human health are highly stable and resistance to degradation. Biphenyl dioxygenase (BPDO) is a bacterial enzyme from Burkholderia xenovorans which has catabolic degradation activity of PCBs. In present study we report simultaneous genetic transformation of three coding components of BPDO enzyme, $b p h A, b p h E$, and $b p h G$ genes, into rose scented geranium (Pelargonum graveolens L.), a fast growing plant with high phytoremediation potential. Toward this end, the $b p h A, b p h E$, and $b p h G$ genes were cloned into pGreen0029 vector. Then, pGreen0029 vector carrying all three genes along with pSoup plasmid were introduced into Agrobacterium tumefaciens strain LBA4404 which then were used for transformation of rose scented geranium. Fully green putative transformant plantlets produced in selection medium were successfully rooted in presence of $50 \mathrm{mgl}^{-1}$ kanamycin. The transgenic nature of fully green and rooted rose scented geranium plantlets were confirmed by Polymerase Chain Reaction (PCR) analysis. Specific primers of $b p h A$ gene (one of the three tandem cloned genes in the vector of this experiment) was used for PCR analysis and produced a $1380 \mathrm{bp}$ fragment which is the exact size of this gene. Transgenic plants were successfully transferred into soil and continued their growth.

Keywords: chlorinated biphenyls, rose scented geranium, Agrobacterium LBA4404, pGreen vector.

\section{INTRODUCTION}

Polychlorinated biphenyls (PCBs), widely used in different industries from 1920 s to 1980 s, are organic chlorinated biphenyl rings with stability and resistance to degradation (Van Aken et al., 2010). These compounds are highly toxic and harmful for human health; therefore their production was banned in 1980s. Nevertheless, worldwide contamination of water and soil with PCBs is one of the important environmental problems at present time (Passatore et al., 2010).

A practical method for soil clean up is phytoremediation and the use of plant-microbe interaction (Furukawa and Fujihara, 2008). Plants can be used to

\footnotetext{
${ }^{1}$ Vida Chalavi (corresponding author: v.chalavi@sanru.ac.ir), Sodabeh Zareh Department of Horticulture, Sari Agricultural Sciences and Natural Resources University, Sari, IRAN

Paper presented at the $7^{\text {th }}$ International Scientific Agricultural Symposium "AGROSYM 2016".

Notes: The authors declare that they have no conflicts of interest. Authorship Form signed online.
} 
initiate pollutants degradation to be followed by bacteria catabolic processes (Mohammady et al., 2007). A bacterial enzyme that involves in catabolic pathway of major soil contaminants, such as polychlorinated biphenyls (PCBs) is biphenyl dioxygenase (BPDO) from Burkholderia xenovorans. Three components of BPDO are a heterodimer oxygenase, (a subunit, $\mathrm{Mr}=51,000$ and b subunit, $\mathrm{Mr}=22,000)$, a ferredoxin $(\mathrm{Mr}=12,000)$ and a ferredoxin reductase $(\mathrm{Mr}=43,000)$. The encoding genes for these enzyme components are $b p h A$ (a subunit), $b p h E$ (b subunit), $b p h F$ (ferredoxin) and $b p h G$ (ferredoxin reductase) (Mohammady et al., 2007).

A way to reduce PCBs contamination is transformation and expression of biphenyl dioxygenase (BPDO) genes having catabolic degradation activity of polychlorinated biphenyls into plants. Plant genetic transformation is being used as a fast track in crop improvement and it is a valuable research tool in plant biology. Transgenic technology has been used for a better yield, resistance to herbicides, improved tolerances to insect infestation as well as better nutritive content, biofuel production, phytoremediation and soil clean up. Among different phytoremediation technologies, transgenic approaches have been described as efficient and promising strategies (Mohammady et al., 2007).

Perhaps the integration and expression of entire genes of a specific biochemical pathway is the ultimate goal of many genetic engineering approaches. However, the majority of experiments reported to date involve the introduction and expression of single genes and the manipulation of multiple genes is still a challenging task. A variety of different methods have been used to transfer multiple genes into plants. These strategies have been sexual crossing plants carrying different transgenes, successive retransformation and cotransformation with several plasmids or single plasmids harboring multiple gene assembly.

Rose scented geranium (Pelargonum graveolens L.) grows fast and has phytoremediation potential (Mahdieh et al., 2013) which could be enhanced by plant genetic transformation. The aim of present study was developing a method for simultaneous transformation of bphA, bphE, and $\mathrm{bphG}$ genes, coding for the components of BPDO enzyme, into rose scented geranium plants.

\section{MATERIALS AND METHODS \\ Plant material and sensitivity to kanamycin}

For developing an efficient regeneration system, shoots of rose scented geranium cv. Attar Rose were surface sterilized and cultured on different combinations of cytokinin (BA) and auxin (NAA).Experimental treatments were 3 concentrations of BA in combination with 3 NAA concentrations with 4 replications in a completely randomized design. Furthermore, sensitivity to kanamycin was tested by exposing in vitro rose scented geranium shoots to 0,10 , $25,50,100 \mu \mathrm{g} \mathrm{ml}^{-1}$ of kanamycin. 


\section{Plasmid constructs}

Binary pGreen0029 (Hellens et al., 2000) vector was chosen for Agrobacterium mediated plant transformation in this study. The T-DNA of pGreen0029 vector contains a kanamycin (Kan) selection marker gene between the nopaline synthase (nos) promoter and nos terminator internal to the T-DNA LB for plant transformation.

For co-transformation with linked transfers in a single plasmid, the following constructs were made. In the first construct, the gel purified EcoRV fragment of 35S-bphA was ligated to blunted KpnI site of the pGreen0029-bphE to produce pGreen0029-bphE+bphA. In the second constract, the gel purified EcoRV fragment of 35S-bphG was cloned into blunted NotI site of the pGreen0029-bphE+bphA (pG-AE) to produce a triple transgenes vector, pGreen0029-bphE+bphA+bphG (pG-AEG). All above recombinant constracts were carefully characterised by restriction mapping.

\section{Plant Transformation}

For producing transgenic rose scented geranium plants,recombinant pGreen0029-bphE+bphA+bphG (pG-AEG)vector along with pSoup plasmid were introduced into Agrobacterium tumefaciens strain LBA4404 (Hoekma et al., 1983) in a mix electroporation. In vitro shoots of rose scented geranium were transferred by leaf disk transformation method (Horsch et al., 1985). Trandgenic shoots were recovered and rooted on MS (Murashige and Skoog, 1962) medium containing $50 \mathrm{mgl}^{-1}$ kanamycin for selection and $500 \mu \mathrm{g} \mathrm{ml} \mathrm{m}^{-1}$ carbenicillin. Positively identified transgenic plantlets were propagated and maintained under 16-hr photoperiod (50-70 $\mu \mathrm{mol} \mathrm{m} \mathrm{m}^{-2} \mathrm{~s}^{-1}$ light intensity) at a temperature of $24^{\circ} \mathrm{C} \pm 1$.

DNA isolation and PCR analysis

Modified CTAB method was used for DNA extraction from rose scented geranium plants. Primers derived from the 5' (5' - ATG AGT TCA GCA ATG AAA -3') and 3' (5' - GGG CTC GGA CAT CAT GCG -3') ends of bphA gene were used for PCR analysis. Amplified DNA fragments were subjected to electrophoresis on a $1.5 \%$ agarose gel and stained with ethidium bromide.

\section{Analysis of data}

Efficient regeneration system was analyzed using a one-way ANOVA. A level of statistical significance at $\mathrm{p}<0.05$ was used in all analyses. The data were analyzed using Procedure-General Linear Model of SAS (version 9.1) software.

\section{RESULTS AND DISCUSSION}

\section{Adventitious shoot regeneration and sensitivity to kanamycin}

In a series of experiments, different plant growth regulator combinations were tested for shoot regeneration of rose scented geranium cv. Attar Rose. A high rate of shoot regeneration (100\%) obtained in the treatment of $2.5 \mathrm{mgl}^{-1} \mathrm{BA}$ in combination with $0.5 \mathrm{mgl}^{-1} \mathrm{NAA}$ and each leaf explants regenerated a few shoots (Figure 1).

Shoot regeneration from leaf explants of rose scented geranium was completely inhibited at $50 \mathrm{mgl}^{-1}$ kanamycin. On medium containing $100 \mu \mathrm{g} \mathrm{ml}^{-1}$ 
kanamycin all shoots became necrotic within 2-3 weeks. On medium containing $100 \mu \mathrm{g} \mathrm{ml}^{-1}$ kanamycin all leaf explants became necrotic within 2-3 weeks. Therefore, in transformation experiments $50 \mathrm{mgl}^{-1}$ of kanamycin was used in the selection medium.

\section{Production of transgenic plants}

Transformation of $3 b p h A, b p h E$, and $b p h G$ genes cloned into pGreen vector were done successfully for rose scented geranium by using Agrobacterium LBA4404. The transformation experiments, resulted in transgenic shoots which regenerated on the medium containing $50 \mathrm{mgl}^{-1}$ kanamycin. Fully green putative transformant plantlets produced in selection medium were successfully rooted in presence of $50 \mathrm{mgl}^{-1}$ kanamycin. Rooted transgenic plants were transferred to soil. With regard to phenotypic appearance, there were no discernible differences between transgenic and non-transgenic plants.

\section{DNA extraction and PCR analysis}

High quality of extracted DNA was confirmed by spectrophotometery and agarose gel electrophoresis. The transgenic nature of fully green and rooted rose scented geranium plantlets were confirmed by Polymerase Chain Reaction (PCR) analysis. Specific primers of bphA gene (one of 3 tendom cloned genes in the vector of this experiment) was used for PCR analysis and produced a $1380 \mathrm{bp}$ fragment which is the exact size of this gene (Figure 2).No amplification was observed for non-transformed rose scented geranium plants (Figure 2). Transgenic plants were successfully transferred into soil and continued their growth.

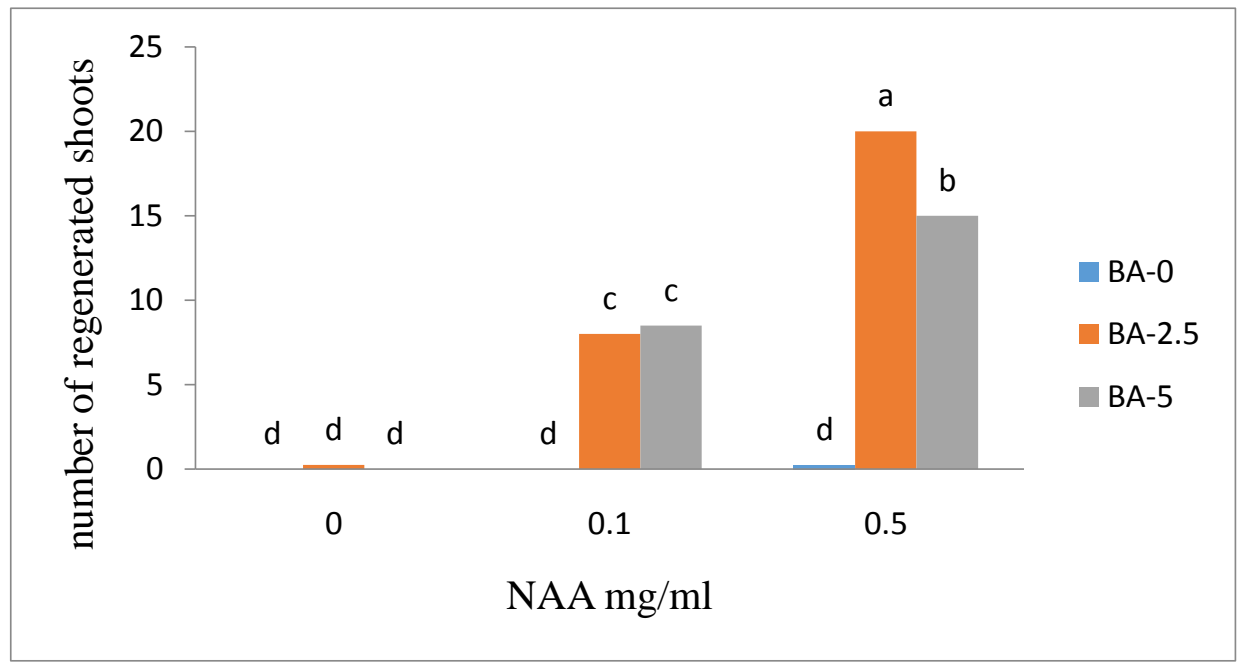

Figure 1. The Effect of different combinations of BA and NAA on adventitious shoot regeneration from leaf explants of rose scented geranium cv. Attar Rose. 


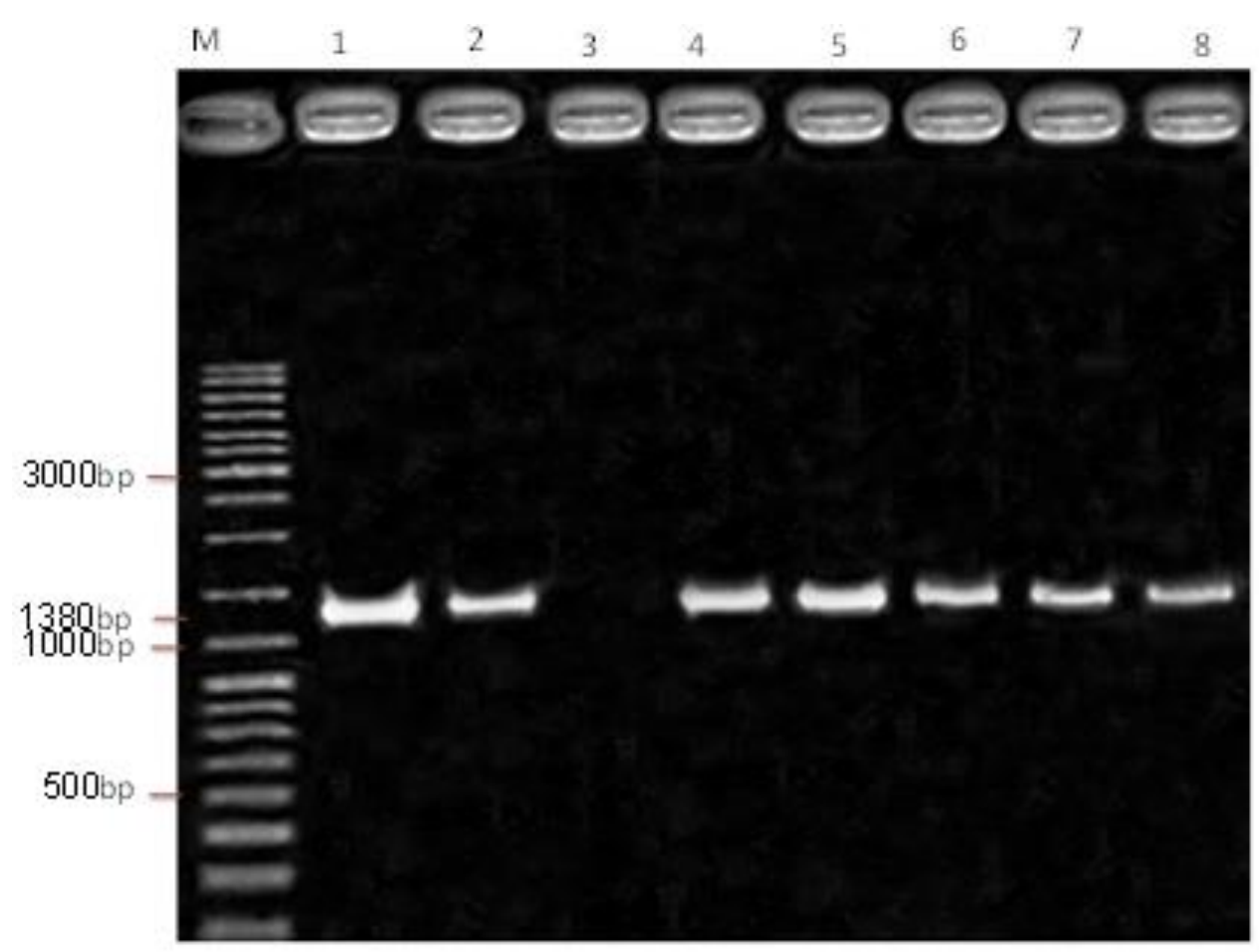

Figure 2. Polymerase chain reaction (PCR) amplification of bphA gene. Lane $\mathrm{M}$, the DNA size standards. Lane 1, DNA from pGreenAEG vector, containing bphE, bphA and bphG genes.lane 3, DNA from non-transformed rose scented geranium plant. Lane 2 and 4-8 DNA from different transgenic rose scented geranium cv. Attar Rose plants.

\section{CONCLUSIONS}

This is a report of successful genetic transformation of rose scented geranium using leaf disk regeneration system. In this study we developed an efficient regeneration and transformation procedure for the rose scented geranium. Adventitious shoot regeneration of this cultivar was made possible by using the optimum combinations of BA and NAA. Kanamycin resistance phenotype combined with PCR analysis confirmed the stable integration of insert genes into rose scented geranium genome. The transgenic lines produced in this study show that plant genetic transformation can be used for improving the phytoremediation potential of rose scented geranium.

\section{REFERENCES}

Furukawa, K., Fujihara, H. (2008): Microbial degradation of polychlorinated biphenyls: Biochemical and molecular features. J. Biosci. Bioeng 105:433-449.

Hellens, R.P., Edwards, E.A., Leyland, N.R., Bean, S., Mullineaux, P.M. (2000): pGreen: a versatile and flexible binary $\mathrm{Ti}$ vector for Agrobacterium mediated plant transformation. Plant MolBiol 42: 819-832. 
Horsch, R.B., Fry, J.E., Hoffmann, N.L.Eichholtz, D., Rogers, S.G., Fraley, R.T. (1985): A simple and general method for transferring genes into plants. Science 227: 1229-1231.

Mahdieh, M., Yazdani, M., Mahdieh, SH. (2013): The high potential of Pelargonium roseum plant for phytoremediation of heavy metals. Environ Monit Assess. 7877788.

Mohammady, M., Chalavi, V., Sura, M., Laliberté, J.F., Sylvestre, M.( 2007): Expression of the bacterial Biphenyl Dioxygenase gene in tobacco plants (Biotechnology \& Bioengineering. Biotechnol.Bioeng. 97: 496-505.

Murashige, T., Skoog, F. (1962): A revise medium for rapid growth and bioassay with tobacco tissue cultures. Physiol. Plant. 15:473-497.

Passatore, L., Rossetti, Juwarkar, A. Massacci, A. (2014): Phytoremediation and bioremediation of polychlorinated biphenyls (PCBs): state of knowledge and research perspectives. Journal of hazardous materials 278: 189-202.

Van Aken, B. A., Correa, P, Schnoor, L. (2010): Phytoremediation of Polychlorinated Biphenyls: New Trends and Promises. Environmental science and Technology, 44(8): 2767-2776. 